Patents and Access and Benefit-sharing Contracts: Conservation or Just More Red Tape?

Dr Charles Lawson

Associate Professor

Australian Centre for Intellectual Property in Agriculture

Griffith Law School

Griffith University

Gold Coast Queensland 4222

$\mathrm{T}-(07) 55527249$

F - (07) 55528667

E-c.lawson@griffith.edu.au 


\title{
Patents and Access and Benefit-sharing Contracts: Conservation or Just More Red Tape?
}

\author{
Dr Charles Lawson*
}

Intellectual property and biodiversity conservation crystallised with the negotiation and implementation of the United Nations” Convention on Biological Diversity (CBD) and the World Trade Organisation's Agreement on Trade Related Aspects of Intellectual Property Rights (TRIPS). Despite an apparent resolution through the CBD’s voluntary Bonn Guidelines on Access to Genetic Resources and Fair and Equitable Sharing of the Benefits Arising out of their Utilization (“Bonn Guidelines”) 1 and the Nagoya Protocol on Access to Genetic Resources and the Fair and Equitable Sharing of Benefits Arising from their Utilization to the Convention on Biological Diversity $^{2}$ there remains little actual consensus. ${ }^{3}$ One of the key questions that remain

*Dr Charles Lawson is an Associate Professor at the Australian Centre for Intellectual Property in Agriculture, Griffith Law School, Griffith University, Queensland, Australia. This work was supported by an Australian Research Council grant DP0987639. A version of this article was presented to a meeting of the Comisión de Derecho Ambiental del Colegio de Abogados (Environmental Law Commission of Mendoza) in Mendoza, Argentina on 19 October 2010.

${ }^{1}$ See Conference of the Parties to the Convention on Biological Diversity, Report of the Sixth Meeting of the Conference of the Parties to the Convention on Biological Diversity, UNEP/CBD/COP/6/20, 27 May 2002, 60-62, 253-269; Conference of the Parties to the Convention on Biological Diversity, Report of the Ad Hoc Open-Ended Working Group on Access and Benefit-Sharing, UNEP/CBD/COP/6/6, 31 October 2001, 14.

${ }^{2}$ Conference of the Parties to the Convention on Biological Diversity, Access to Genetic Resources and the Fair And Equitable Sharing of Benefits Arising from their Utilization, UNEP/CBD/COP/10/L.43/Rev.1, 29 October 2010. See also Conference of the Parties to the Convention on Biological Diversity, Report of the First Part of the Ninth Meeting of the Ad hoc Open Ended Working Group on Access and Benefit-Sharing, UNEP/CBD/COP/10/5/ADD3, 16 August 2010; Conference of the Parties to the Convention on Biological Diversity, Report of the Second Part of the Ninth Meeting of the Ad Hoc Open Ended Working Group on Access and Benefit-Sharing, UNEP/CBD/COP/10/5/ADD4, 28 July 2010; and so on.

${ }^{3}$ See Conference of the Parties to the Convention on Biological Diversity, Report of the Third Part of The Ninth Meeting of the Ad Hoc Open-Ended Working Group on Access and Benefit-Sharing, UNEP/CBD/COP/10/5/Add.5, 17 October 2010, 4; Conference of the Parties to the Convention on Biological Diversity, Report of the Ninth Meeting of the Conference of the Parties to the Convention on 
to be settled is the interaction between patents and biodiversity conservation, and the role of patents in promoting biodiversity conservation, recalling the CBD specifically provided that intellectual property should support the CBD’s objectives including biodiversity conservation and sustainable use (Art 16(5)). ${ }^{4}$

This article considers market-based instruments (contracts, patents, and so on) as a policy mechanism for achieving environmental protection goals. The analysis is situated in Australia and the Australian legal system as a developed nation that specifically recognises a role for patents as capturing some of the benefits from possible uses of biodiversity and passing them to those that conserve biodiversity:

Australia has a legislative framework in place to ensure that when new products or scientific advances are generated using genetic information from Australian species, Australia shares a portion of the benefits. This allows a portion of any profits to aid biodiversity conservation in the area the native species came from.

Biological Diversity, UNEP/CBD/COP/9/29, 9 October 2008, 32-33 and 109-118; Conference of the Parties to the Convention on Biological Diversity, Report of the Eighth Meeting of the Conference of the Parties to the Convention on Biological Diversity, UNEP/CBD/COP/8/31, 15 June 2006, 34-38 and 128-138; Conference of the Parties to the Convention on Biological Diversity, Report of the Seventh Meeting of the Conference of the Parties to the Convention on Biological Diversity, UNEP/CBD/COP/7/21, 13 April 2004, 34 and 298-303. See also General Assembly of the United Nations, United Nations Millennium Declaration, 55th Session, A/RES/55/2, 8 September 2000.

${ }^{4}$ The internationally contested inherent conflicts between TRIPs and the CBD are that TRIPs requires genetic materials be protected by patents or a sui generis plant variety that privately appropriates genetic resources over which a country has sovereign rights under the CBD, and that these privileges do not also require the additional measures set out in the CBD, such as prior informed consent, mutually agreed terms and benefit sharing: see, for example, Council for Trade-Related Aspects of Intellectual Property Rights, The Relationship Between the TRIPs Agreement and the Convention on Biological Diversity - Summary of Issues Raised and Points Made, IP/C/W/368/Rev.1, 8 February 2006, 4; Council for Trade-Related Aspects of Intellectual Property Rights, The Relationship Between the TRIPs Agreement and the Convention on Biological Diversity - Summary of Issues Raised and Points Made, IP/C/W/368/Rev.1/Corr.1, 9 March 2006, 2. See also Secretariat of the Convention on Biological Diversity, Handbook of the Convention on Biological Diversity 207-213 (3 ${ }^{\text {rd }}$ ed. 2005). 
Benefit-sharing agreements are negotiated between the jurisdiction that the genetic material is sourced from and the organisation using it. These are commercial contracts and normal commercial practice applies regarding intellectual property (emphasis added). ${ }^{5}$

The article is structured as follows: the next part addresses the "market failure" for biodiversity conservation and the incentive theory that justifies the regulation of access and benefit-sharing in Australia. The following part outlines the regulation of access and benefit-sharing in Australia and the role and place of patents. This is really setting the scene and the context for the agreements between the resource holders and bio-prospectors that include terms and conditions about patents, and specifically the contractual arrangements: first the Craig Venter Institute contract and then the Griffith and AstraZeneca Partnership agreement(s). These examples were chosen because, in the case of the Craig Venter Institute contract, it has been made publicly available, and the Griffith University and AstraZeneca Partnership, because a review was funded by the Commonwealth Department of the Environment, Water, Heritage and the Arts to support the Australian Government's contention about the benefits delivered by it's access and benefit-sharing regulation. ${ }^{6}$ Both these examples demonstrate that there is little evidence that benefits actually flow to conservers and curators of in situ biodiversity (such as protected areas). The article then concludes that there are credible questions about whether there really are benefits from these arrangements. This is a significant concern because if attempts to regulate access and benefit sharing merely impose additional costs and inefficiencies on the transactions (a regulatory burden) without benefits flowing through to promoting biodiversity conservation, then other more efficient and efficient regulatory mechanisms ${ }^{7}$ should be considered.

\footnotetext{
${ }^{5}$ Commonwealth of Australia, Australia's Fourth National Report to the United Nations Convention on Biological Diversity 40 (2009).

${ }^{6}$ See note 5, supra 42.

${ }^{7}$ Regulation should be both "efficient” in terms of "minimizing compliance and other costs imposed on the community” and "effective” in "addressing an identified problem”: Productivity Commission, Regulation and Its Review 2002-03, Annual Report Series 1 (2003).
} 


\section{The "market failure” and biodiversity conservation incentives}

As a generalisation, market based economies like Australia have addressed biodiversity conservation as a market failure. ${ }^{8}$ This approach reflects the theory that the benefits of biological diversity conservation accrue to society and cannot be sufficiently captured by those likely to undertake the conservation - the marginal private returns from conservation activities do not correspond with their marginal social returns favouring biological diversity destruction and decline. ${ }^{9}$ In addressing the market failure Australia has adopted a range of methods to incentivise biodiversity conservation. ${ }^{10}$ Significantly, in determining an access and benefit-sharing scheme implementing the CBD's obligations and applying to the Commonwealth, there were four "overarching principles, or desirable features" including that the regulation "provide incentives for the conservation and sustainable use of biological

\footnotetext{
${ }^{8}$ See Department of the Environment and Heritage, Understanding the Nationally Consistent Approach for Access to and the Utilisation of Australia's Native Genetic and Biochemical Resources 2 (2002). See also Organisation of Economic Co-operation and Development, Handbook of Incentive Measures for Biodiversity: Design and Implementation (1999).

${ }^{9}$ See Charles Lawson, Regulating Access to Biological Resources: The Market Failure for Biodiversity Conservation, 24(1) Law in Context 137, 138 (2006).

${ }^{10}$ These include, for examples, direct grants for "achieving efficient, sustainable and equitable management of natural resources in Australia” under the Landcare scheme in the Natural Resources Management (Financial Assistance) Act 1992 (Cth), tax deduction for gifts of property and capital gains tax exemption for gifts of property as "cost effective incentives for conservation and protection of the environment for the benefit of all Australians” under the Income Tax Assessment Act 1997 (Cth) s 31-5, and so on. Unfortunately there is no clearly articulated policy reason for having Patents Act 1990 (Cth) patents in Australia other than they have been around for hundreds of years and they are mandatory as part of a global trading regime to comply with the World Trade Organisation's Agreement on Trade-Related Aspects of Intellectual Property Rights [1995] A.T.S. 38 and the Australia-United States Free Trade Agreement [2005] A.T.S. 1: see Charles Lawson and Catherine Pickering, 'TRIPs-Plus' Patent Privileges - An Intellectual Property 'Cargo Cult' in Australia, 22(4) Prometheus 355, 363-366 (2004). There are vague and poorly articulated justifications about incentives to invent, incentives to disclose, and so on, but these are never clearly stated or justified: see Charles Lawson, Implementing an Objective of the Convention on Biological Diversity - Intellectual Property, Access to Genetic Resources and Benefit-sharing in Australia, 22(2) Environmental and Planning Law Journal 130, 144-152 (2005).
} 
resources". ${ }^{11}$ The final form of the regulation under the Environment Protection and Biodiversity Conservation Act 1999 (Cth) and the Environment Protection and Biodiversity Conservation Regulations 2000 (Cth) establishes biodiversity as an object of transaction by regulating access and benefit-sharing, clearly defining what was to be exchanged and then imposing obligations on the subsequent users of any accessed biological resources to share the benefits according to the terms and conditions of a contract. ${ }^{12}$ This same Commonwealth approach has been replicated in the Queensland Biodiscovery Act 2004 (Qld) and the Northern Territory Biological Resources Act 2006 (NT). ${ }^{13}$ In short, this approach allows part of the social value for individual economic activities to be appropriated, thus compensating those likely to undertake the conservation activities, and providing an incentive to undertake future conservation activities. ${ }^{14}$ The contract is the favoured instrument because it allows private actors to set the terms and conditions of their transaction that is best suited to their particular circumstances: a meeting of minds agreeing to the exchange of access to biodiversity for a "price” agreed between the parties. The "price” comprising: money; transfer of technology; training; infrastructure; access to new information; intellectual property; and so on. ${ }^{15}$

\footnotetext{
${ }^{11}$ Department of Environment and Heritage, Access to Biological Resources in Commonwealth Areas 5-6 (2000).

${ }^{12}$ See Productivity Commission, Impacts of Native Vegetation and Biodiversity Regulations, Inquiry Report No 29 189-197 (2004); Productivity Commission, Constraints on Private Conservation of Biodiversity, Commission Research Paper 5-7 (2001). See also Organisation for Economic Cooperation and Development, Handbook of Market Creation for Biodiversity: Issues in Implementation 15-47 (2004); Ad Hoc Open-Ended Working Group on Access and Benefit-sharing, Compilation of Submissions Provided by Parties, Governments, Indigenous and Local Communities and Relevant Stakeholders in Preparation for the Third Meeting of the Ad Hoc Open-Ended Working Group on Access and Benefit-sharing, UNEP/CBD/WG-ABS/3/INF/1/Add.1, 25 January 2005.

${ }^{13}$ Other States and Territories have indicated that they will adopt a similar approach: see Department of the Environment and Heritage, note 8, supra.

${ }^{14}$ See, e.g., Josef Janssen, Property Rights on Genetic Resources: Economic Issues, 9(4) Global Environmental Change 313, 316 (1999).

${ }^{15}$ See UNEP/CBD/COP/6/20, note 1 supra 267-269.
} 
For our purposes patents are a part of the price for access. ${ }^{16}$ Typically this will be an agreement where the contract will set out that if any of the accessed materials are subject to a patent then the parties agree to share some of the benefits that flow from the commercialisation of the patent protected product or process. ${ }^{17}$ Typically this will be a share of royalties, but it can also include sharing patent protected technology, access to know how, training, and so on (addressed further below). So the particular patent contribution, at least in theory, is by capturing some of the value from innovative, creative and useful applications of the accessed biological resources and returning this as part of the price paid for access. Importantly, not only do patents contribute to the price, they also contribute to the incentive to conserve biodiversity by privatising some of the value. Recall that the solution to the market failure for biodiversity conservation was to allow part of the social value for individual economic activities to be appropriated, thus compensating those likely to undertake the conservation activities, and providing an incentive to undertake future conservation activities.

This theory provides a measure against which the policy and implementation of access and benefit-sharing arrangements can be assessed: whether the marginal private returns from conservation activities are sufficient to at least correspond with their marginal social returns? If the private returns are less, then the destruction and decline of biological resource stock, rather than its conservation, can be expected. To be effective in addressing biodiversity conservation the private returns need, in large part, to be in money to pay for fences, eradicating weeds, controlling feral animals, establishing protected areas, and so on. These aspects are considered in the context of

\footnotetext{
${ }^{16}$ The intended relationship between intellectual property and biodiversity conservation is that: "Patents and other forms of intellectual property then take their place and role in delivering a part of the compensation (and incentive) contributing to the marginal private return. This is achieved, at least in theory, by capturing some of the value from innovative, creative and useful applications of the accessed biological resources and returning this as part of the price paid for access and use of the biological resources through royalties or other benefits, such as, for example, access to and transfer of a new technology” (footnote omitted): Charles Lawson, The Role of Patents in Biodiversity Conservation, 27(11) Nature Biotechnology 994, 994 (2009).

${ }^{17}$ See, for example, Department of the Environment and Heritage, Biological Resources Access Agreement between the Commonwealth of Australia and the Craig J Venter Institute (2004).
} 
the contracts after briefly outlining the regulatory schemes for biodiversity conservation and patents in Australia.

\section{Domestic regulation of biodiversity conservation}

The Australian regulation of various aspects of biodiversity conservation is diverse and considerable. ${ }^{18}$ In response to the CBD and the Bonn Guidelines, ${ }^{19}$ formal regulation of access and benefit-sharing has been adopted by the Commonwealth (Environment Protection and Biodiversity Conservation Act 1999 (Cth)), Queensland (Biodiscovery Act 2004 (Qld)) and the Northern Territory (Biological Resources Act 2006 (NT)) in respect of land under government controls. ${ }^{20}$ Other privately held lands in those jurisdictions and the other unregulated jurisdictions (New South Wales, Victoria, South Australia, Tasmania and Norfolk Island) determine access and benefit-sharing as a private (unregulated) agreement between the land holder and

\footnotetext{
${ }^{18}$ See, for examples, Environment Protection and Biodiversity Conservation Act 1999 (Cth);
} Biodiscovery Act 2004 (Qld); Nature Conservation Act 1992 (Qld); Marine Parks Act 1997 (NSW); Fisheries Management Act 1994 (NSW); National Parks and Wildlife Act 1974 (NSW); Parks Victoria Act 1998 (Vic); Fisheries Act 1995 (Vic); Flora and Fauna Guarantee Act 1988 (Vic); National Parks Act 1975 (Vic); Wildlife Act 1975 (Vic); Fisheries Management Act 2007 (SA); Wilderness Protection Act 1992 (SA); Native Vegetation Act 1991 (SA); National Parks and Wildlife Act 1972 (SA); Fish Resources Management Act 1994 (WA); Conservation and Land Management Act 1984 (WA); National Parks and Reserves Management Act 2002 (Tas); Nature Conservation Act 2002 (Tas); Threatened Species Protection Act 1995 (Tas); Living Marine Resources Management Act 1995 (Tas); Biological Resources Act 2006 (NT); Territory Parks and Wildlife Conservation Act 2001 (NT); Nature Conservation Act 1980 (ACT).

${ }^{19}$ See note 11 , supra.

${ }^{20}$ For example, Environment Protection and Biodiversity Conservation Act 1999 (Cth) s 528 and Environment Protection and Biodiversity Conservation Regulations 2000 (Cth) r 8A.01 that limits the reach of the regulatory arrangements to “Commonwealth areas” meaning “(a) land owned by the Commonwealth or a Commonwealth agency (including land owned in Norfolk Island) and airspace over the land; (b) an area of land held under lease by the Commonwealth or a Commonwealth agency (including an area held under lease in Norfolk Island) and airspace over the land; (c) land in: (i) an external Territory (except Norfolk Island); or (ii) the Jervis Bay Territory; and airspace over the land; (d) the coastal sea of Australia or an external Territory; (e) the continental shelf, and the waters and airspace over the continental shelf; (f) the waters of the exclusive economic zone, the seabed under those waters and the airspace above those waters; (g) any other area of land, sea or seabed that is included in a Commonwealth reserve”. 
bioprospector. ${ }^{21}$ In essence the Commonwealth regulation requires an access permit (nil for non-commercial purposes and otherwise costing approximately AUD\$50 ( US\$40; €25): Environment Protection and Biodiversity Conservation Regulations 2000 (Cth) r 18.02(1)) and for commercial or potential commercial uses of the accessed materials a benefit-sharing agreement between the parties is required based on "terms mutually agreed”, "adequate benefit-sharing arrangements including, that if practicable, some benefits would be used for biodiversity conservation in the area from which the resource was obtained" and "prior informed consent of any Indigenous owners”. ${ }^{22}$ The model contracts (merely suggestions as a starting place for negotiation) for the access and benefit-sharing agreement address benefits for the use of Indigenous knowledge, threshold payments (for example, pharmaceutical, nutraceutical or agricultural purposes then payments, for gross revenue received from commercialisation of nil for less than AUD\$500 000, 2.5\% for between AUD\$500 000 - 5000000 and 5\% for more than AUD\$5 000000 ( US\$4 500000 million; €2 500 000), and various additional benefits including ad hoc research, research funding to a local research institution, joint ventures with an Australian research institution or an Australian company, capacity building, technology transfer and scientific research and development programmes. ${ }^{23}$ The model contract also addresses "proposals to benefit biodiversity conservation in [the] access area” and provides:

Benefits may include (but are not limited to) improved knowledge of: biodiversity; taxonomy; biological and ecological processes; impacts of environmental change; or data and knowledge that will assist in the conservation and management of the environment. ${ }^{24}$

\footnotetext{
${ }^{21}$ Approximately 60 per cent of land in Australia is under private ownership and management: see note 5, supra 16. Conservation on private lands raises other difficult problems that may be affected and undermined by regulation of adjacent lands covered by a different regulatory arrangement: see Productivity Commission, Constraints on Private Conservation of Biodiversity, Commission Research Paper (2001).

${ }^{22}$ Minister for the Environment and Heritage, Environment Protection and Biodiversity Conservation Amendment Regulations 2005 (No 2) Explanatory Statement, Select Legislative Instrument No 2511 (2005). See also Environment Protection and Biodiversity Conservation Regulations 2000 (Cth) r 8A.07(1).

${ }^{23}$ Department of the Environment, Water, Heritage and the Arts, Model Benefit-sharing Agreement Commonwealth and Access Party 26-30 (2009).

${ }^{24}$ Ibid 26.
} 
Importantly, the model contract defines "intellectual property” to include "copyright; all rights in relation to inventions (including patent rights); all rights in relation to plant varieties (including plant breeders rights); registered and unregistered trademarks (including service marks), designs, and circuit layouts; all other rights resulting from intellectual activity; know-how (whether patentable or not)". ${ }^{25}$ The contract then provides that any "intellectual property" vests in the bioprospector and that subsequent dealings with intellectual property (such as licenses and assignments) must be consistent with the model contract and that the Commonwealth "will continue to receive an equitable share of the benefits arising from subsequent use" ${ }^{26}$ The significance of this arrangement is that the Commonwealth is giving away any claims to intellectual property in exchange for the bioprospector promising to share a portion of gross monies received from retail sales of the materials or products containing the material. ${ }^{27}$ So far there have been approximately 60 permits issued and seven benefitsharing contracts completed (Department of the Environment, Water, Heritage and the Arts 2009, pers. comm.). The actual terms and conditions agreed are confidential, albeit the "mutually agreed terms for benefit-sharing followed the model contracts provided by [Department of the Environment, Water, Heritage and the Arts] closely” (Department of the Environment, Water, Heritage and the Arts 2009, pers. comm.). To date there is no record that amounts have been paid according to these agreements. Further, any monies received by the Commonwealth would go straight to the consolidated revenue, and would need to be appropriation. ${ }^{28}$ There are no appropriations of any monies hypothecated from access and benefit sharing arrangements for any particular conservation activities (such as a 'Special Account” associated with access and benefit-sharing agreements).

Under the Environment Protection and Biodiversity Conservation Regulations 2000 (Cth) r 8A.05(1) the Australian Antarctic Division, the Great Barrier Reef Marine

\footnotetext{
${ }^{25}$ Ibid 4.

${ }^{26}$ Ibid 8-9.

${ }^{27}$ Ibid 3-4 and 26-27.

${ }^{28}$ See Charles Lawson, Re-invigorating the Accountability and Transparency of the Australian Government's Expenditure, 32(3) Melbourne University Law Review 879, 881-890 (2008).
} 
Park Authority, the Australian National Botanic Gardens and the Australian Institute of Marine Science have been declared able to enter into their own access and benefitsharing arrangements with bioprospectors. Under these arrangements approximately 400 permits have been issued (Department of the Environment, Water, Heritage and the Arts 2009, pers. comm.). The terms and conditions of any access and benefitsharing contracts are not disclosed because they are confidential. Under these arrangements so far, only “in-kind” benefits have been received (Department of the Environment, Water, Heritage and the Arts 2009, pers. comm.).

\section{Domestic regulation of patents}

The Commonwealth’s Patents Act 1990 (Cth) is a statutory scheme conferring a privilege to dealings with the idea in the patent protected product or process together with control over how the patent protected product or process is used. The Patents Act 1990 (Cth) threshold requirements are: a "patentable invention” and this includes almost any product or process; novelty; inventive step (non-obviousness) and a description of the invention so that others can perform the invention (s 18). Once these threshold requirements are satisfied the applicant gets a patent and "the exclusive rights, during the term of the patent, to exploit the invention and to authorise another person to exploit the invention” (s 13). The "exclusive rights are personal property and are capable of assignment and of devolution by law” and comprise, for 20-25 years, to "make, hire, sell or otherwise dispose of the product, offer to make, sell, hire or otherwise dispose of it, use or import it, or keep it for the purpose of doing any of these things" and use the method or process or do any of these things with the product of the method or process (s 13 and sch 1). The Patents Act 1990 (Cth) complies with TRIPS and the later TRIPS-plus Australia-United States Free Trade Agreement. ${ }^{29}$

The Commissioner of Patents exercises her statutory powers according to a range of policy and guidance materials that contribute to the environment (or the matrix of legalities) in which decisions are made including devolved management, the outcomes and outputs framework, and that the Commissioner is employed with

\footnotetext{
${ }^{29}$ See Lawson and Pickering, note 10, supra.
} 
"performance" incentives aligned with the outcomes and outputs. ${ }^{30}$ The important point here is that the Commissioner's incentives are directed to the "customers" applying for patents, and she has absolutely no concerns about environmental perspectives and the interaction between patents and biodiversity conservation imperatives. $^{31}$

\section{Craig J Venter Institute contract}

The biological resources access agreement between the Commonwealth of Australia and the Craig J Venter Institute in 2004 is publicly available and provides an illustration of the kinds of access and benefit-sharing agreements in place and the kinds of benefits that flow from these arrangements. ${ }^{32}$ The genesis of this agreement was the global voyage in 2003 of the of the Sorcerer II with Craig Venter and various scientists to unlock the secrets of the oceans by sampling, sequencing and analyzing the DNA of the microorganisms living in the oceans. ${ }^{33}$ When the Sorcerer II came to Australian waters to collect samples they needed to formalize this arrangement through an agreement with the Commonwealth of Australia (the federal government). At the time the Commonwealth's access and benefit-sharing regulation was still being negotiated and did not commence until 1 December $2005 .{ }^{34}$ The recitals indicate that the agreement was negotiated in contemplation of the CBD's commitments and Australia's adoption of the Bonn Guidelines that formed the foundation for the later regulatory scheme:

B - As a party to the Convention on Biological Diversity (CBD), Australia is committed to the conservation of biodiversity, the sustainable use of its components, and equitable sharing of benefits derived from its use, and has embraced the "Bonn Guidelines on Access to Genetic

\footnotetext{
${ }^{30}$ See Charles Lawson, Managerialist Influences on Granting Patents in Australia, 15(2) Australian Journal of Administrative Law 70, 71-87 (2008).

${ }^{31}$ See ibid 87-90.

32 See note 17 , supra.

${ }^{33}$ See Rusch et al., The Sorcerer II Global Ocean Sampling Expedition: Northwest Atlantic through Eastern Tropical Pacific, 5 PLoS Biology 398, 7 (2007) (e77. doi:10.1371/journal.pbio.0050077). See also Matthew Rimmer, The Sorcerer II Expedition: Intellectual Property and Biodiscovery, 6 Macquarie Journal of International and Comparative Environmental Law 147 (2009).

${ }^{34}$ See Environment Protection and Biodiversity Conservation Amendment Regulations 2005 (No 2) (Cth) r 2.
} 
Resources and Fair and Equitable Sharing of the Benefits Arising out of their Utilization” which were adopted by the CBD Conference of the Parties in 2002.

C - The Collaborator is undertaking a global sampling expedition to survey microorganisms that live in the oceans, and in some places soils, to better understand overall species diversity, discover and characterize new bacterial and viral species, evaluate the ecological roles that dominant (but generally unculturable) microbes play in the ecosystem, and establish a freely shared, global environmental genomics database that can be used by scientists around the world for any purpose.

E - Australia seeks to maximise the benefits to the nation arising from allowing access to its biodiversity, from access to the genomic data reflecting the biodiversity of other nations, and from contributing with other nations to a freely-shared global environmental genomics database; such benefits specifically including improvements in Australia’s knowledge base about its own biodiversity and its capacity for effective conservation, and research and development participation by Australian individuals and organisations.

The intellectual property provisions provided:

5.1 - All property rights in and in relation to the Materials and the Results, including Intellectual Property arising (directly or indirectly) from the Collaborator's use of the Materials or the Results vests, or will vest, in Australia.

5.2 - Without limiting clause 5.1, all Intellectual Property rights arising from use of the Materials, the Results or any Derivative other than for the Approved Research, or from any other breach of this agreement by the Recipient, will vest in Australia.

The phrase "intellectual property" was defined to mean:

1.1(h) ... statutory and other proprietary rights in respect of copyright and neighbouring rights; all rights in relation to inventions, patents, plant varieties, registered and unregistered trade marks, registered and unregistered designs, circuit layouts and confidential information, but does not include moral rights that are not transferable. 
Essentially, in return for permission to collect the samples, Venter agreed that the Materials and Results would vest in Australia, and that any intellectual property arising for any uses of the Materials or Results will also vest in Australia.

The “Approved Research” under the contract was to:

Inventory the microorganisms that live in oceans within Australia's jurisdiction, and in soils in some places within Australia or its Territories, to better understand overall species diversity, discover and characterize new bacterial and viral species, evaluate the ecological roles that dominant (but generally unculturable) microbes play in the ecosystem, and establish and publish a freely shared, global environmental genomics database that can be freely used by any person or entity.

The results of the research were then made freely available through the Community Cyberinfrastructure for Advanced Marine Microbial Ecology Research and Analysis database (or CAMERA database) at the website http://camera.calit2.net/. ${ }^{35}$ One of the conditions of using the database is:

As a condition of my use of the CAMERA website, I acknowledge and agree that the genetic information available through the CAMERA website may be considered to be part of the genetic patrimony of the country from which the sample was obtained. As a user, I agree to: (1) acknowledge the country of origin in any publications where the genetic information is presented; (2) contact the CBD focal point identified on the CBD website if I intend to use the genetic information for commercial purposes. ${ }^{36}$

The "the CBD focal point identified on the CBD website" (or “CBD NFP”) for Australia is the Commonwealth Department of the Environment, Water, Heritage and the Arts. ${ }^{37}$ Any monies received by the Commonwealth would go straight to the consolidated revenue, and with no appropriation for particular conservation activities,

\footnotetext{
${ }^{35}$ See Seshadri et al., CAMERA: A Community Resource for Metagenomics, 5 PLoS Biology 394 (2007) (e75 doi:10.1371/journal.pbio.0050075).

${ }^{36}$ CAMERA Registration, Why Do We Require Users to Register for CAMERA? (2009), available at https://web2.camera.calit2.net/gridsphere/gridsphere?cid=request (last visited 6 September 2010).

${ }^{37}$ See Secretariat of the Convention on Biological Diversity, National Focal Points (2009).
} 
those monies are not hypothecated for any activities. ${ }^{38}$ So far there have been no contacts for commercial uses and no payments made. The principal outcome of the collection of samples in Australian waters has been a contribution to the CAMERA database that now comprises many millions of sequences and billion of base pairs.

\section{Griffith University and AstraZeneca as a Partnership}

The Queensland Biodiscovery Collaboration in the partnership between Griffith University and AstraZeneca for Natural Product Discovery starting in 1993 and formally ending in 2007. ${ }^{39}$ The partnership was established in response to Australian Government's “Factor f” scheme that was an incentive scheme where, in return for investments in the research or manufacture of pharmaceuticals, the Australian Government would pay a higher price for a company’s drugs under the universal health scheme. ${ }^{40}$ There were also other contributions, such as from the Queensland Department of State Development, although the extent of these other contributions is not entirely clear. ${ }^{41}$ The partnership was formalised through a contract between Griffith University and AstraZeneca - unfortunately this is, and remains, confidential so we only have reports about what it provided. ${ }^{42}$ Significantly, the reports state the sample collection was subcontracted to predominantly the Queensland Herbarium and the Queensland Museum, and that AstraZeneca retained all intellectual property:

\footnotetext{
${ }^{38}$ See Lawson, note 28, supra, 881-890.

${ }^{39}$ See Department of the Environment, Water, Heritage and the Arts, Queensland Biodiscovery Collaboration: The Griffith University AstraZeneca Partnership for Natural Product Discovery - An Access \& Benefit-sharing Case Study, UNU-IAS Report 7 (2008). Other sample collections have been established by the Australian Institute of Marine Science (a "bioresource library”) and between the Australian Institute of Marine Science and the Western Australian Museum, the latter promising to “enable timely and co-ordinated access to samples with full legal compliance”: Australian Institute of Marine Science, 08-09 Annual Report 4 and 8 (2009). The collection is reportedly being used by the Western Australian Institute of Medical Research to screen for potentially bio-active compounds, albeit the terms and conditions for access this collection remains unclear and confidential: ibid 8.

${ }^{40}$ See Department of the Environment, Water, Heritage and the Arts, ibid 19.

${ }^{41}$ See ibid 19-20.

42 Ibid.
} 
Griffith University retains ownership over the biota samples and compound libraries that resulted from the partnership. Intellectual property rights to commercial products developed from the partnership remain with AstraZeneca. ${ }^{43}$

The reports also state that AstraZeneca invested more than AUD\$100 million during the term of the partnership, that was spent as follows: AUD\$45 million to build the research unit at Griffith University; AUD\$9 million annually to running costs; and AUD\$9 million for the collection of samples by partner institutions. ${ }^{44}$ The monetary benefits were reported as fees for samples (or to cover the costs of an agreed-upon work plan) and royalties, and royalties that may or may not materialize (noting that none have yet). ${ }^{45}$ The non-monetary benefits were reported as the provision of vehicles, equipment, technology, training, building of a state-of-the-art natural product discovery unit, and increased knowledge of biodiversity. ${ }^{46}$ More generally the cited benefits were:

The AstraZeneca/Griffith University collaboration initiated in 1993 has contributed valuable monetary and non-monetary benefits to Queensland. The collaboration contributed to the understanding of Queensland's plant and marine biota with the discovery of 37 new plant species and nearly 1500 new marine organisms. It also resulted in more than [AUD]\$100 million in investment in biodiscovery R\&D in Queensland and created 43 fulltime jobs and directly supported some of the research work of the Queensland Herbarium and the Queensland Museum. The types of jobs created have expanded Queensland's highly skilled workforce, and attracted new scientists to Queensland. ${ }^{47}$

The only monies going to conservers and curators of in situ biodiversity may have been the fees paid for samples, being a portion of the AUD\$9 million paid to the collecting institutions. The ongoing use of the samples collected as part of the Queensland Biodiscovery Collaboration now contribute to research and partnerships of the Eskitis Institute for Cell and Molecular Therapies for novel drug- and cellbased therapies for human diseases in the thematic areas of cancer, infection and

\footnotetext{
${ }^{43}$ Ibid 30.

${ }^{44}$ Ibid 30.

${ }^{45}$ See ibid 28.

${ }^{46}$ See ibid 28.

${ }^{47}$ Ibid 33.
} 
immunity, neglected diseases, neurodegenerative diseases, and stem cell biology. ${ }^{48}$ The intellectual property arrangements and whether any monies are provided to conservers and curators of in situ biodiversity from where these samples were collected are unclear.

\section{Australian government access and benefit-sharing policy}

A significant part in understanding the role and place of patents is the policy environment and the conception of patents as a part of conserving biodiversity. As set out about, in addressing the market failure Australia has adopted a range of methods to incentivise biodiversity conservation, including patents as a contribution to the price for access. The concern is that patents are an economic instrument directed to incentivising innovation and creation, and bringing new products and services to markets that overturn concentrations of market power. ${ }^{49}$ In the context of biodiversity conservation patents have been co-opted as a means of redistributing the value of the genetic resources from the consumer purchasing the bioprospector's (or their licensees or assignees) products or services to the conserver. The model adopted by the CBD was a market-oriented property rights contract between the bioprospector and resource holder to redistribute the value of the genetic resources from the consumer purchasing the bioprospector's (or their licensees or assignees) products or services to the conserver with source nations establishing the terms and conditions

\footnotetext{
${ }^{48}$ See http://www.griffith.edu.au/science/eskitis-institute-cell-molecular-therapies (last visited 8 September 2010).

${ }^{49}$ Unfortunately the policy objectives for patents in Australia remain uncertain, there being no clear articulation other than generalised initiatives to improve business investment in innovation, stimulate growth of innovative firms, strengthen commercial linkages between publicly funded research institutions and industry and take promising research to the stage of commercial viability: see Charles Lawson, Patent Privileges and the National Competition Policy - Patent Scope and Allocation?, 33(1) Australian Business Law Review 7 (2005). The policy objectives are relevant because good quality and performing regulation is important: "Regulations are an essential component of modern society. When regulations work well, they enhance governance and promote stability, progress and prosperity. By contrast, ill conceived or poor quality regulations can create barriers to trade and commerce, impede innovation and increase business costs and consumer prices”: Productivity Commission, Regulation and Its Review 2004-2005, Annual Report Series 1 (2005).
} 
(“national sovereignty”). ${ }^{50}$ This marked a significant shift from the conception of genetic resources as part of the "common heritage of humanity" reflected in earlier agreements such as the Food and Agriculture Organisation of the United Nations” International Undertaking on Plant Genetic Resources for Food and Agriculture in 1983 and the free exchange of genetic resources. ${ }^{51}$ The CBD also contrasts with the approach under the Food and Agriculture Organization of the United Nations” International Treaty on Plant Genetic Resources for Food and Agriculture in 2004 that is a top-down compensatory model of a "tax" on commercialisation of accessed materials with an international organisation distributing the funds to curators, farmers and indigenous groups. ${ }^{52}$

The CBD itself recognised that existing intellectual property might undermine the biodiversity conservation objectives espoused by the agreed scheme. CBD expressly recognising: "that patents and other intellectual property rights may have an influence on the implementation of this [CBD]" and "that such rights are supportive of and do not run counter to its objectives” (Art 16(5)). When the Australian Government started to implement its commitments under the CBD the National Strategy for the Conservation of Australia's Biological Diversity (1996) expressly recognised that conflicts between biodiversity conservation and other policy prescriptions was a concern:

The development of integrated policies for major uses of biological resources is necessary to coordinate activities within and between all levels of government, to ensure that the full social and

\footnotetext{
${ }^{50}$ See Shayana Kadidal, Plants, Poverty, and Pharmaceutical Patents, 103(1) Yale Law Journal 223, 231-237 (1993).

${ }^{51}$ See Food and Agriculture Organization of the United Nations, Report of the Conference of FAO, $22^{\text {nd }}$ Session §§ [275]-[285] (1983).

52 See Charles Lawson, Intellectual Property and the Material Transfer Agreement under the International Treaty on Plant Genetic Resources for Food and Agriculture, 31(5) European Intellectual Property Review 244, 252-254 (2009). See also Stephen Brush, Indigenous Knowledge of Biological Resources and Intellectual Property Rights: The Role of Anthropology, 95(3) American Anthropologist 653, 661-666 (1993).
} 
environmental consequences, and the opportunity costs, of development activities are considered, and to ensure that the public interest is properly taken into account. ${ }^{53}$

A few years later, when it actually came to developing the access to biological resources regulations the Australian Government in the Nationally Consistent Approach for Access to and the Utilisation of Australia's Native Genetic and Biochemical Resources espoused a policy of "reassurance should be provided that arrangements do not alter existing property or intellectual property law”. ${ }^{54}$ More recently the Australian Government has heralded the benefits of existing intellectual property standards in Genetic Resources Management in Commonwealth Areas: Sustainable Access > Shared Benefits heralding that Australia has a "comparative advantage ... with a well-respected and long established system of commercial and intellectual property law that offers security to investors". ${ }^{55}$ This was a pronouncement directed to legal provenance and promoting investment in biological resource-based product research and development. ${ }^{56}$

Most recently, Australia’s Biodiversity Conservation Strategy 2010-2020 does not even mention access and benefit-sharing in the context of the CBD. ${ }^{57}$ Presumably the policy settings in the current regulations and their application mean that accessing and benefit-sharing has been satisfactorily addressed. ${ }^{58}$ The concern remains, however,

\footnotetext{
${ }^{53}$ Department of the Environment, Sport and Territories, National Strategy for the Conservation of Australia’s Biological Diversity 25 (1996).

${ }^{54}$ Department of the Environment and Heritage, note 8, supra 7.

${ }^{55}$ Department of the Environment and Heritage, Genetic Resources Management in Commonwealth Areas: Sustainable Access > Shared Benefits 1 (2005).

${ }^{56}$ See ibid 6; Department of the Environment and Heritage, Australia: The Right Environment for Biodiscovery 2 (2006).

${ }^{57}$ See National Biodiversity Strategy Review Task Group, Biodiversity Conservation Strategy 20102020 (2009).

58 The Independent Review of the Environment Protection and Biodiversity Conservation Act 1999 (Interim Report) in 2009 addressing access and benefit-sharing biological resources did not address intellectual property: “There appears to be little need for a change to the permitting system. From the information received, however, more compliance and enforcement action is required and the penalties for non-compliance should be strengthened”: Department of the Environment, Water, Heritage and the Arts, Independent Review of the Environment Protection and Biodiversity Conservation Act 1999,
} 
that perhaps these policy settings that are reflected in the current contract-based access and benefit-sharing arrangements are more suited to legal provenance and promoting investment in biological resource-based product research and development, and contrary to the CBD's express requirement "to ensure that such [intellectual property] rights are supportive of and do not run counter to its [the CBD's] objectives” (Art 16(5)).

\section{Discussion}

This article shows that patents are involved in the debates about biodiversity conservation and that there is some useful thinking about their role and effectiveness from an economic perspective. To be effective the benefits flowing from access and benefit-sharing contracts need to be private returns that, in large part, are money to pay for fences, eradicating weeds, controlling feral animals, establishing protected areas, and so on. Other non-monetary benefits, while undoubtedly significant, are unlikely to promote biodiversity conservation as effectively as they are more in the nature of social benefits. Both the Craig Venter Institute contract and the Griffith and AstraZeneca Partnership agreement(s) demonstrate that there are valuable and useful benefits flowing from these arrangements. Thus the conclusions form the report about the Griffith University/AstraZeneca partnership:

\footnotetext{
Monetary and non-monetary benefits in this case fall within the standard package for "best practice”, but it is in the accumulated and multi-faceted nature of the benefits that the real gains for the State and country are to be found. These include the collections and compound libraries, the advanced natural product discovery unit, and the enormous gains in taxonomic and ecological understanding that resulted from the collections. This case demonstrates that these benefits can be of equal, or greater, importance to the potential monetary benefits from royalties should a product be commercialized. ${ }^{59}$
}

But both the Craig Venter Institute contract and the Griffith and AstraZeneca Partnership agreement(s) also demonstrate that the likely benefits are not easily

\footnotetext{
Interim Report 252 (2009). A similar conclusion was presented in the Final Report: Department of the Environment, Water, Heritage and the Arts, Independent Review of the Environment Protection and Biodiversity Conservation Act 1999, Final Report 137 (2009).

${ }^{59}$ Department of the Environment, Water, Heritage and the Arts, note 39, supra, 35.
} 
privately appropriable. Thus, from the Craig Venter Institute contract there have been no commercialisation agreements from the results used from the CAMERA database obtained from Australian materials, and that has been no cash out of this arrangement. On this basis, the other uses of the oceans and waterways, like fishing, mining, and so on, look like much better prospects and much more likely uses of these oceans and waterways than biodiversity conservation. In other words, the social returns are good, but the private returns appear very limited. Significantly, however, this agreement maintains control over intellectual property with the prospect of intellectual property contributing to future private returns. And from the Griffith and AstraZeneca Partnership the price paid of AUS\$100 million over 14 years with a whole range of benefits in equipment, technology, training, and increased knowledge of biodiversity, and so on, but less that AUD\$9 million has gone to those actually conserving biodiversity in the form of royalties for collection. ${ }^{60}$ Again, the social returns are commendable, but the private returns are limited. And again, the other uses of the lands like farming, forestry, mining, and so on, look like much better prospects and much more likely uses of those lands than biodiversity conservation. Significantly, this partnership gave away control over intellectual property to AstraZeneca with no prospect of intellectual property contributing to future private returns to conservators from AstraZeneca. Presumably, the current holders of this collection, the Eskitis Institute for Cell and Molecular Therapies, have the ability to control some intellectual property claims although it is not clear whether they would transfer any monetary benefits to conservators. ${ }^{61}$

The other conclusion from this article's analysis is that the policy integrating biodiversity conservation and patents do not appear to be in harmony, with a preference for maintaining exiting patent standard irrespective of their consequences for biodiversity conservation. This is making no judgement about whether investment, and scaring investors with weaker patents, should over-ride biodiversity conservation. Rather the conclusion is that preferring patents to biodiversity conservation has

\footnotetext{
${ }^{60}$ See ibid 30.

${ }^{61}$ See http://www.griffith.edu.au/science/eskitis-institute-cell-molecular-therapies (last visited 8 September 2010).
} 
consequences for biodiversity conservation and this is about its destruction and decline.

Importantly, this article shows that there are credible questions about whether there really are private returns from these arrangements accessing biodiversity and whether patents are contributing positively. But, most significantly, this article demonstrates that attempts to regulate access and benefit sharing appear to merely impose additional costs and inefficiencies on the transactions (a regulatory burden) without benefits flowing through to promoting biodiversity conservation. If this is accepted, other more effective and efficient regulatory mechanisms need to be considered.

The recent conclusion of the Nagoya Protocol on Access to Genetic Resources and the Fair and Equitable Sharing of Benefits Arising from their Utilization to the Convention on Biological Diversity, ${ }^{62}$ while heralding a consensus, probably has few consequences for the likely benefits actually flowing from accessed genetic resources. The major impact of this protocol is likely to be only on the need to address traditional knowledge (where relevant) and ensure that accessed materials are adequately documented in their subsequent uses. The protocol is neither binding nor prescriptive about the form or content of benefits that should be addressed in access and benefit sharing arrangements.

\footnotetext{
${ }^{62}$ See note 2, supra.
} 